ISSN: 2162-3104 Print/ ISSN: 2166-3750 Online

Volume 8, Issue 1 (2018), pp. 233-250

(C) Journal of International Students

http://jistudents.org/

doi: 10.5281/zenodo.1134299

\title{
Exploring the Relationship Among International Students' English Self-efficacy, Using English to Learn Self-efficacy, and Academic Self-efficacy
}

\author{
Chih-hsuan Wang \\ Jamie Harrison \\ Victoria Cardullo \\ $\mathrm{Xi}$ Lin \\ Auburn University, United States
}

\begin{abstract}
One of the major challenges for international students to pursue academic goals in the United States is English language proficiency, which often negatively affects academic success. Even students with confidence in their English language proficiency encounter challenges using English in class. Previous research indicates self-efficacy positively predicts English language proficiency and academic achievement. Therefore, the current study hypothesized a model using self-efficacy in using English to learn as a mediator between English and academic self-efficacy. The structural equation modeling results indicate English self-efficacy indirectly influenced international students' academic self-efficacy through their using English to learn self-efficacy. Findings suggest using English and using English to learn self-efficacy are two distinct constructs. These results warrant academic English support for non-native English speaking international students.
\end{abstract}

Keywords: academic self-efficacy, English self-efficacy, international students

The number of international students enrolled in higher education institutions in the United States has dramatically increased in the past 
decade. In 2001, there were about 110,000 international students in higher education, whereas in 2012 that number rose to 524,000 students (Ruiz, 2014). Moreover, in the 2014-2015 academic year, international students enrolled in higher educational institutions increased to 975,000 in the United States (Zong \& Batalova, 2016). International students bring several benefits to American students and institutions in the United States (i.e., tuitions, academic contributions, cultural awareness, and diversity experiences on campus; Luo \& Jamieson-Drake, 2013; Perry, 2016; Sherry, Thomas, \& Chui, 2010). However, they also face many challenges. For example, international students often have a sense of alienation and homesickness due to the distance from their native land. In addition, international students must acculturate to a new culture and environment. They need to become familiar with different teaching and pedagogical approaches to pursue their academic goals in the United States (Burdett \& Crossman, 2012; Perry, 2016; Sherry et al., 2010).

Among all of the above-mentioned challenges, English language proficiency is considered one of the major challenges that often contributes to other challenges (Perry, 2016). Even if international students have successfully passed the requirements of English language examinations before studying in the United States, many of them still do not have competent English language skills (Burdett \& Crossman, 2012; Perry, 2016). The lower levels of English language skills are found to be closely related to higher levels of feelings of discrimination, higher levels of homesickness, and higher levels of anxiety when taking classes in the United States (Lin \& Sherz, 2014; Perry, 2016; Poyrazli \& Lopez, 2007).

\section{English Self-Efficacy}

According to social cognitive theory, self-efficacy is indicative of one's beliefs about the capabilities of what he/she can do in a specific domain (Bandura, 1986, 1997). Self-efficacy has an effect on an individual's task choice, the amount of efforts put into the task, and persistence on the task. It also influences academic motivation, learning, and achievement (Bandura, 1997; Choi, 2005; Pintrich \& Schunk, 1996; Schunk \& Pajares, 2002). In other words, students with positive self-efficacy are willing to put more effort into and be more persistent on the academic tasks they choose. In addition, they usually have higher levels of academic motivation and better performance. According to the definition, English self-efficacy in the current study can be defined as an individual's belief or confidence in 
his/her ability to use the English language to communicate with others, understand English conversations, read materials, and write in English.

Students' English self-efficacy is strongly related to their actual English language proficiency. For example, Rahimi and Abedini (2009) indicated that English listening comprehension self-efficacy was significantly related to English language listening proficiency. In addition, Brady-Amoon and Fuertes (2011) suggested self-efficacy was a significant predictor of adjustment and academic performance. Further, Poyrazli, Arbona, Nora, McPherson, and Pisecco (2002) indicated a poor adjustment to a new culture could negatively influence international students' academic self-efficacy. Specifically, they found reading-writing English language proficiency strongly contributed to international students' adjustment level which then influenced their level of academic self-efficacy. In other words, international students with poor English language skills tend to struggle to adjust to an English-focused learning environment; in turn, this leads to a lower level of academic self-efficacy. Previous research also indicated English language proficiency is the major focus of academic adjustment and the key for international students to be successful, both socially and academically (Andrade, 2006; Sherry et al., 2010). Therefore, intensive English language supports, such as writing and conversational skills, are critical for non-native English speaking international students (Andrade, 2006; Ramburuth, 2001; Sherry et al., 2010).

Wang (2004) developed a Questionnaire of English Self-Efficacy (QESE) to measure listening, speaking, reading, and writing, the four dimensions of English language proficiency of non-native English speakers. According to research, students with low English self-efficacy demonstrated lower levels of self-regulated learning strategies. On the other hand, higher levels of English self-efficacy students reported more self-regulated learning strategies (Kim, Wang, Ahn, \& Bong, 2015). In addition, high English reading self-efficacy readers often used more reading strategies to facilitate their reading than low English reading self-efficacy readers (Lin \& Wang, 2010).

\section{Academic Self-Efficacy}

Previous research demonstrated that academic self-efficacy is a strong predictor of students' academic achievement (Bong, 2001; Choi, 2005; Ferla, Valcke, \& Cai, 2009; Klomegah, 2007). For example, Bong's (2001) research indicated course-specific self-efficacy as predictors for midterm and final grades of college students in South Korea. Ferla et al. (2009) 
examined the relationship between math self-efficacy and Program for International Student Assessment (PISA) math scores of 15-year-old students using a 2003 PISA survey dataset and found that math self-efficacy strongly predicted math performance. In addition, Klomegah's (2007) research showed academic self-efficacy was a strong predictor which can be used to predict course grades of college students in the United States. Moreover, Zajacova, Lynch, and Espenshade (2005) found self-efficacy is a strong predictor of academic performance for non-traditional, minority, and immigrant students. In other words, the relationship between self-efficacy and academic performance is positive and similar across different cultures.

The relationship between academic self-efficacy and academic performance is similar across cultures, yet it has differences (Klassen, 2004). Research results showed Asian students had lower self-efficacy than American students, but their academic performance was better than American students (Whang \& Hancock, 1994; Yan \& Gaier, 1994). Whereas Asian-American students demonstrated more modest levels of selfefficacy than their non-Asian peers, they had higher levels of performance than their non-Asian peers (Eaton \& Dembo, 1997). In addition, Salili, Chiu, and Lai (2001) researched the relationships between academic self-efficacy and high school performance among Hong Kong Chinese students and Canadian Chinese students. They found that the relationship between academic self-efficacy and high school performance was stronger in Canadian Chinese students than in the Hong Kong Chinese students group.

\section{Using English to Learn Self-Efficacy as a Mediator}

As mentioned earlier, English language proficiency is the key for the adjustment socially and academically of international students which lead to higher levels of academic self-efficacy (Andrade, 2006; Sherry, et al., 2010). Although the research found there was a positive relationship between Test of English as a Foreign Language (TOEFL) scores and GPAs (Messner \& Liu, 1995; Stoynoff, 1997), some other research found a contrasting result that English language proficiency does not directly influence international students' academic self-efficacy. Berman and Cheng (2001) investigated the relationship between TOEFL scores and GPAs of undergraduate and graduate non-native and native English speaking students. They found that graduate non-native English speakers received higher TOEFL scores than undergraduate non-native English speakers; however, they received lower GPAs than their graduate peers while undergraduate non-native English speakers performed as proficient as their 
undergraduate peers. Fass-Holmes and Vaughn (2015) found similar results. They investigated the scores in English composition and/or English as a second language class and GPAs of non-native English speaking international students who did not reach the University required TOEFL scores before starting their enrollment. Their findings suggested TOEFL is highly correlated with international students' scores in English courses, but it does not correlate with their GPAs. In other words, English language proficiency did not necessarily lead to academic success.

Andrade (2009) interviewed and surveyed non-native English speaking international students to understand the challenges they encountered as they adjusted to university life in the United States. She found that non-native English speaking international students had certain levels of confidence in their English language proficiency upon arriving on the campus. However, the research indicated students were not confident in taking classes with all native English speakers. They were often uncomfortable to speak out or to participate in group discussions in class. They indicated they were afraid to ask questions to American students or instructors even though they perceived their English language proficiency had improved over time. In addition, non-native English speaking international students indicated several problems related to understanding lectures and small group discussions (e.g., instructors spoke fast or used idioms or slang) (Andrade, 2009; Lin \& Scherz, 2014). They articulated that speaking and writing were more challenging than reading and listening while taking classes (Andrade, 2009; Berman \& Cheng, 2001; Lin \& Scherz, 2014). On the other end of the spectrum, some students stated they had no problems completing their academic goals even if they had little to no confidence in using the English language in the class (Andrade, 2009).

Levels of self-efficacy in English language proficiency of nonnative English speaking international students does not guarantee confidence in using the English language in the classroom as they pursue their degrees. In addition, previous research in the relationships between self-efficacy in English language proficiency and academic self-efficacy yielded conflicting results. In light of these findings, researchers in the current study hypothesized a model to demonstrate the relationship among self-efficacy in English language proficiency, self-efficacy when using the English language to learn, and academic self-efficacy. The model illustrated that self-efficacy in English language proficiency directly or indirectly influences academic self-efficacy through students' self-efficacy in using the English language to learn. In other words, the authors hypothesized that self-efficacy when using English to learn is the mediator between self- 
efficacy in English language proficiency and academic self-efficacy. The purpose of the current study was to determine the relationship among selfefficacy in English language proficiency, self-efficacy in using English to learn, and academic self-efficacy of non-native English speaking international students.

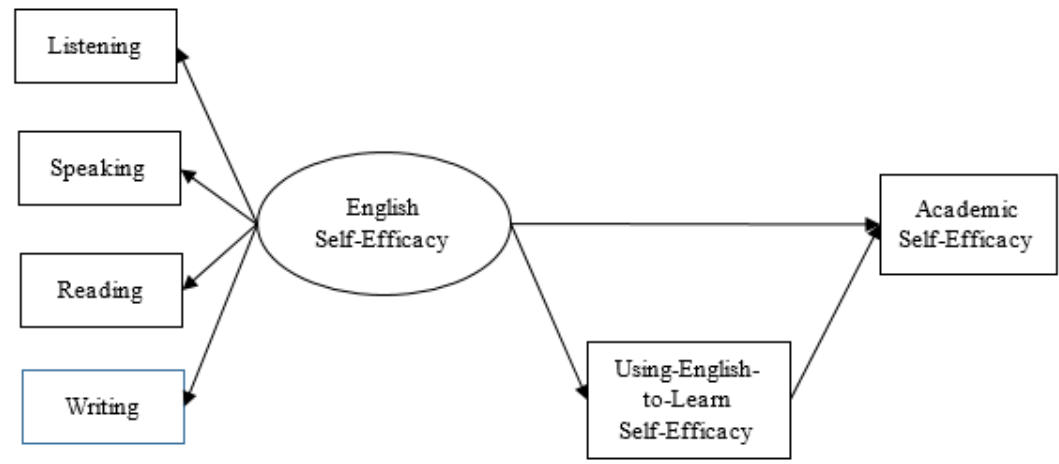

Figure 1. Hypothesized model.

\section{RESEARCH METHOD}

The current study was conducted to examine the relationship between English self-efficacy, the self-efficacy in using English to learn, and academic self-efficacy for non-English native speaking international students. The study was approved by the Institutional Review Board at a southeastern university in the United States.

\section{Participants}

A convenience sampling procedure was used to recruit participants. International students in one southeastern university were invited to participate in the study through the university multicultural center weekly emails. Since the invitations were sent out via a third party, researchers did not know how many invitations had been sent. Two hundred and eighteen students responded to the survey, but two of them were English native speakers. Therefore, these two participants were excluded from the data analysis. All responding participants completed at least $90 \%$ of the survey items. A regression estimation method was used to replace the missing values. The useable response rate was $99.1 \%$. 
Among the 216 participants, $96(44.4 \%)$ of them were male, whereas 56 (25.9\%) were females. Sixty-four students $(29.6 \%)$ did not indicate their gender. Their age range was from 19 to 43 years old with the mean age at $27.71(S D=4.66)$. On average, they have studied English for 13.76 years (range $=0-30, S D=6.38$ ). The average duration they lived in the United States was 2.82 years (range $=0-20, S D=2.60$ ). Among the participants, $16(7.4 \%)$ of them considered themselves as Caucasian, five $(2.3 \%)$ of them came from Africa, nine $(4.2 \%)$ of them were Hispanic or Latino, $116(53.7 \%)$ came from Asia, five (2.3\%) of them came from the Middle East, and the rest of them did not specify where they came from. Nine students were undergraduate students $(4.2 \%)$ while the majority of the students were graduate students (masters: $n=58,26.9 \%$; doctorate: $n=86$, $39.8 \%)$. Sixty-three students (29.2\%) did not report their educational level.

\section{Procedure}

The multicultural center at the southeastern university sent out the invitation emails to international students who were currently enrolled in the university as of March, 2016. Students clicked on the link provided in the invitation email. After clicking the link, students were able to read the informed consent and decide if they were willing to participate in the study. The survey was anonymous and students were able to withdraw by closing the browser at any time during the survey which took about 10-20 min to complete. After completing the survey, students were able to enter a random drawing to receive one of six Amazon Kindle Fires as a gift of appreciation. Two reminders were sent out the following week and two weeks later after the invitation emails were sent to students.

\section{Measures}

The measures in the current study included demographic questions, the Modified Questionnaire of English Self-efficacy (modified from Wang, 2004), the Using English to Learn Self-Efficacy Scale (modified from Solberg, O'Brien, Villareal, Kennel, \& Davis, 1993), and the academic selfefficacy subscale adapted from the Motivational Strategies and Learning (Pintrich, Smith, Garcia, \& McKeachie, 1993). 


\section{Questionnaire of English Self-Efficacy}

The Questionnaire of English Self-Efficacy (QESE) was originally developed by Wang in 2004. The scale consists of 32 seven-point Likerttype items, focused on English self-efficacy in English language proficiency for listening, speaking, reading, and writing of non-native English speakers. Participants responded to each item from not at all confident (1) to extremely confident (7). The higher scores indicated the higher level of English self-efficacy. The instrument has been validated using college students (Wang, Kim, Bai, \& Hu, 2014) via confirmatory factor analysis and yielded a good fit. The reliability coefficients were .97 for the entire scale, and were between .88 to .92 for subscales. The convergent validity was .52 and criterion-related validity was .58. In the current study, researchers modified the original questionnaire to reflect the lifestyle and characteristics of the current international student population on the southeastern campus in the United States. The internal consistency Cronbach's alpha reliability coefficient for English self-efficacy was: listening .92 (seven items); speaking .92 (six items); reading .91 (six items); and writing .85 (five items). For the entire scale the Cronbach's alpha score was .97. The total scores of each subscale were computed by averaging item responses.

\section{Using English to Learn Self-Efficacy Scale}

The Using English to Learn Self-Efficacy Scale (UETLSES) was modified from College Self-Efficacy Inventory (CSEI; Solberg et al., 1993). The original inventory consisted of 20 ten-point Likert-type items measuring college students' confidence in adjusting to academic challenges, social environments, and roommates. The internal consistency reliability of the original inventory ranged from .62 to .89 , and the authors also found that the CSEI scale was negatively correlated with physical and psychological problems and positively correlated with academic persistence and social integration (Solberg et al., 1993, 1998). In the current study, researchers modified the academic adjustment self-efficacy subscale and modified it to Using English to Learn Self-Efficacy Scale. For example, researchers modified the original question "ask a question in class" to "I can ask questions in English in class." Researchers also added several questions related to the challenges in using English to learn that international students usually encountered, such as "I can understand new reading materials selected by my instructors." The final Using English to Learn Self-Efficacy Scale consisted of 15 seven-point Likert-type items. Participants responded 
to each item from not at all confident (1) to extremely confident (7). The higher scores indicated that students had a higher level of self-efficacy in using English to learn. The internal consistency reliability Cronbach's alpha in the current study was .97. The total scores of UETLSES were computed by averaging the item responses.

\section{Academic Self-Efficacy Scale}

The academic self-efficacy scale was adapted from Motivational Strategies and Learning Questionnaire (MSLQ; Pintrich et al., 1993). Participants responded to these eight items using a seven-point Likert-type scale, ranging from not at all true of me (1) to very true of me (7). The higher scores indicated the higher level of academic self-efficacy. The internal consistency reliability Cronbach's alpha was .93, and the confirmatory factor analysis yield an acceptable fit according to Pintrich, et al. (1993). In the current study, the internal consistency reliability Cronbach's alpha was .88. The total scores of academic self-efficacy were computed by averaging the item responses.

\section{Data Analysis Method}

The Statistical Package for Social Science (SPSS) 23.0 and AMOS 23.0 were used as the statistical software to analyze the data. The hypothesized model was examined using covariance-based structural equation modeling (SEM) with maximum likelihood estimation. The SEM is a multivariate data analysis procedure that can examine relationships among multiple latent variables and the relationships among latent variables and manifest variables simultaneously. In addition, it can be used to investigate the mediator effect (Hair, Black, Babin, Anderson, \& Tatham, 2006; Tabachnick \& Fidell, 2007).

The SEM uses model fit indices to evaluate the fit of the model, including goodness-of-fit test (Chi-square), goodness-of-fit index (GFI), comparative fit index $(C F I)$, normed fit index (NFI), Tucker-Lewis index $(T L I)$, and root means square error of approximation (RMSEA). In order to reach a good fit, the Chi-square test with non-statistical significance is preferred. However, in order to conduct a SEM analysis, a large sample size is required which also leads to statistical significance in the Chi-square test. Therefore, other fit indices provided useful information for a model fit evaluation. The general rule of thumb for the cut-off value of fit indices is .90 for GFI, CFI, NFI, and TLI. The REMSEA needs to be less than .8. In 
addition, the ratio of Chi-square over degrees of freedom needs to be less than three (Meyers, Gamst, \& Guarino, 2006). After evaluating the hypothesized model, researchers can improve the model fit by adding paths according to modification indices or deleting nonsignificant paths based on a trimming process (Hox \& Bechger, 1998; Kline, 2010; Ullman \& Bentler, 2013). Whenever adding or deleting one path, the modified model needs to be re-evaluated until the model reaches an adequate fit (Hox \& Bechger, 1998).

\section{RESULTS}

The variables included in the current study were: English Self-efficacy for Listening, Speaking, Reading, and Writing, English Self-efficacy, Using English to Learn Self-efficacy, and Academic Self-efficacy. Table 1 summarized the descriptive statistics for each variable. In order to examine the linear relationship among the latent variables and among the manifest variables and their corresponded latent variable, a bivariate Pearson correlation was conducted. The correlation coefficients among latent variables ranged from .50 to .57 , indicating the linear assumption among latent variables was not violated. In addition, the correlation coefficients among manifest variables and their corresponded latent variables ranged from .94 to .95 , indicating the linear assumption was assumed (Table 2).

Table 1. Descriptive statistics for each variable $(N=216)$.

\begin{tabular}{ccccc}
\hline Variable & \# of Items & Cronbach's alpha & $M$ & $S D$ \\
\hline English self-efficacy & 24 & .97 & 6.08 & 0.89 \\
English self-efficacy for listening & 7 & .92 & 5.86 & 1.06 \\
English self-efficacy for speaking & 6 & .92 & 6.21 & 0.91 \\
English self-efficacy for reading & 6 & .91 & 6.23 & 0.88 \\
English self-efficacy for writing & 5 & .85 & 6.01 & 0.93 \\
Using English to learn self-efficacy & 15 & .97 & 6.19 & 0.89 \\
Academic self-efficacy & 8 & .88 & 5.82 & 0.96 \\
\hline
\end{tabular}

Table 2. Bivariate correlation results.

\begin{tabular}{|c|c|c|c|c|c|c|c|}
\hline & 1. & 2. & 3. & 4. & 5. & 6. & 7. \\
\hline 1.English self-efficacy & 1 & & & & & & \\
\hline English self-efficacy for listening & $.94 * *$ & 1 & & & & & \\
\hline English self-efficacy for speaking & $.95 * *$ & $.83^{* *}$ & 1 & & & & \\
\hline English self-efficacy for reading & $.94^{* *}$ & $.84^{* *}$ & $.88^{* *}$ & 1 & & & \\
\hline 5. English self-efficacy for writing & $.95 * *$ & $.86^{* *}$ & $.87^{* *}$ & $.87 * *$ & 1 & & \\
\hline 6.Using English to learn self-efficacy & $.95 * *$ & $.88 * *$ & $.92^{* *}$ & $.90 * *$ & $.89 * *$ & 1 & \\
\hline 7.Academic self-efficacy & $.54 * *$ & $.52^{* *}$ & $.47^{* *}$ & $.54 * *$ & $.50 * *$ & $.57 * *$ & 1 \\
\hline
\end{tabular}




\section{Hypothesized Model}

The initial results for the hypothesized model reached an acceptable fit between the hypothesis model and the observed data (See Figure 1, Table 3 , and Table 4). The Chi-square test was statistically significant, $\chi^{2}(8)=$ $21.10, p=.007$, and the ratio between Chi-square statistic over degrees of freedom was less than $3, \chi^{2} / d f=2.64$. Further, the fit indices $G F I, C F I, N F I$, and $T L I$ were $.968, .992, .987$, and .985 , which indicated a good fit. However, the RMSEA was .087, which indicated an acceptable fit, and the path from English Self-Efficacy to Academic Self-Efficacy was not statistically significant, $p=.69$ and did not demonstrate practical significance either, $\beta=-0.12$. Therefore, the hypothesized model was respecified by deleting non-significant paths and/or modification indices.

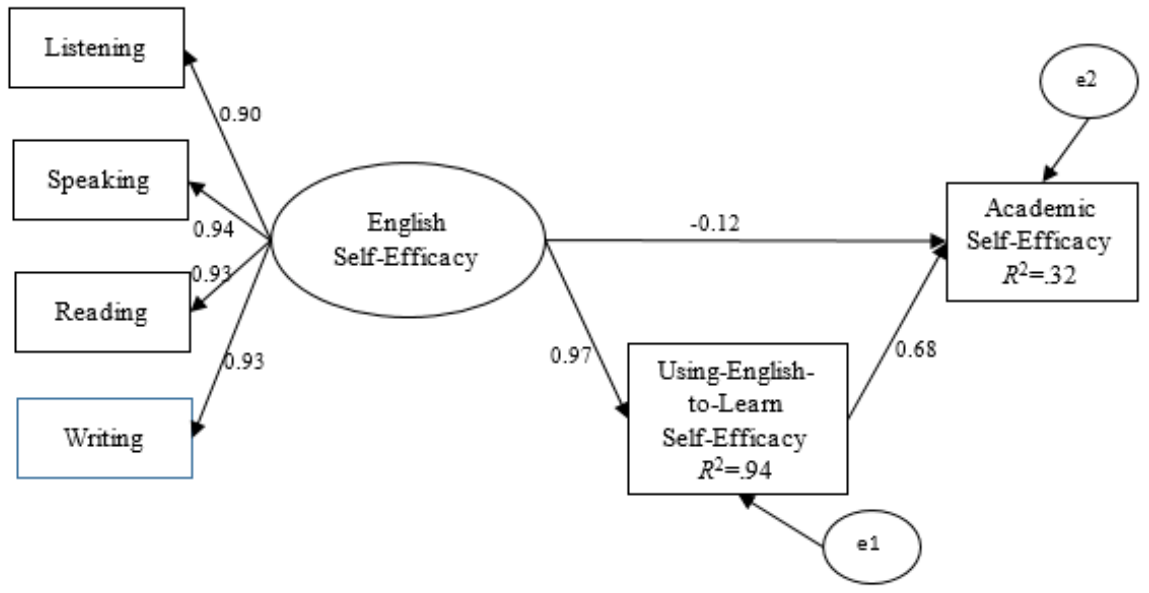

Figure 2: Hypothesized model estimates.

$\chi^{2} / d f=2.638 ; G F I=.968 ; C F I=.992 ; N F I=.987 ; T L I=.985 ; R M S E A=.087$

\section{Final Model}

Figure 3, Table 3, and Table 4 summarize the final model. The results indicated a good fit between the final model and the observed data. Even the Chi-square test was still statistically significant, $\chi^{2}(8)=16.11, p=$ .04 , and the ratio between Chi-square statistic and degrees of freedom was less than $3, \chi^{2} / d f=2.01$. In addition, all fit indices indicated a good fit, $G F I$ $=.976, C F I=.995, N F I=.990, T L I=.990$, and $R M S E A=.069$. Finally, all 
the path coefficients were statistically significant $(p<.05)$ and also demonstrated practical significance $(\beta>0.3)$. The endogenous variable of Using English to Learn Self-Efficacy accounted for a large amount of variance with $R^{2}=.94$. The endogenous variable of Academic Self-Efficacy also accounted for a large amount of variance with $R^{2}=.32$. In addition, the manifest variable English Self-Efficacy for Listening, Speaking, Reading, and Writing accounted for a large amount of variance $R^{2}=.82, .89, .87$, and .86. According to the final model, international students' English selfefficacy affected their self-efficacy in using English to learn, hence, led to their academic self-efficacy. In other words, international students with higher levels of English self-efficacy usually had higher levels of selfefficacy in using English to learn. With a higher level of self-efficacy in using English to learn, international students usually had a higher level of academic self-efficacy. Finally, self-efficacy in using English to learn was a mediator between English self-efficacy and academic self-efficacy.

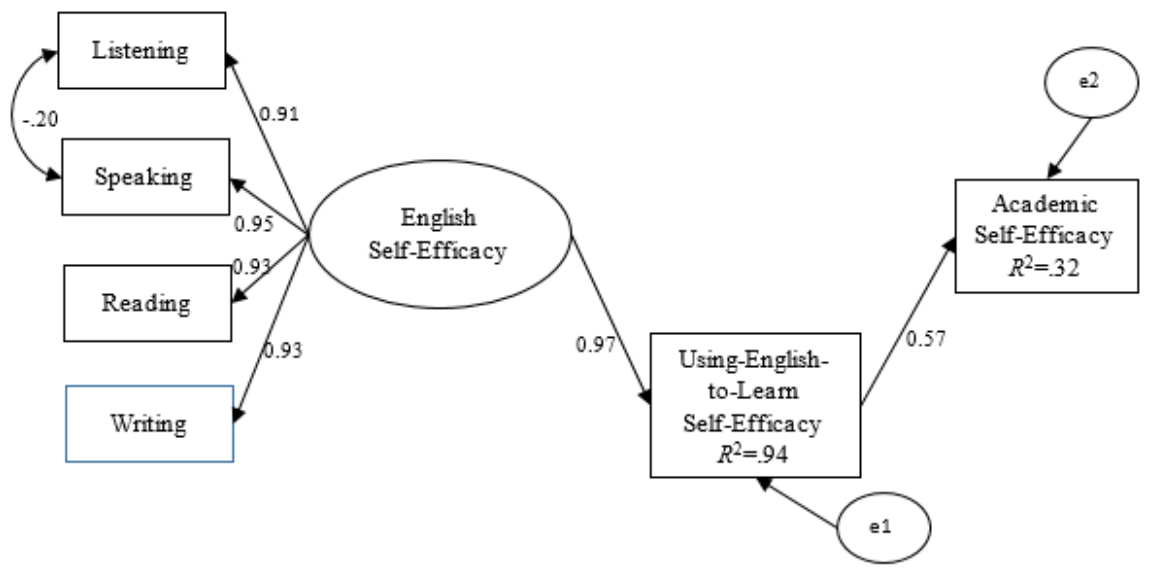

Figure 3:|Final model estimates.

$\chi^{2} / d f=2.013 ; G F I=.976 ; C F I=.995 ; N F I=.990 ; T L I=.990 ; R M S E A=.069$

Table 3. Model fit indices.

\begin{tabular}{cccccccccc}
\hline Model & $\chi^{2}$ & $d f$ & $p$ & $\chi^{2} / d f$ & GFI & CFI & NFI & TLI & RMSEA \\
\hline Hypothesized & 21.100 & 8 & .007 & 2.638 & .968 & .992 & .987 & .985 & .087 \\
\hline Final & 16.106 & 8 & .041 & 2.013 & .976 & .995 & .990 & .990 & .069 \\
\hline
\end{tabular}




\section{DISCUSSION AND CONCLUSIONS}

The purpose of this study was to examine the relationships among three aspects of self-efficacy: English self-efficacy, self-efficacy in using English to learn, and academic self-efficacy for non-English native speaking international students. The researchers hypothesized that international students' English self-efficacy influences their academic self-efficacy through self-efficacy in using English to learn. Results of the study suggest that non-native English speaking international students' use of English to learn self-efficacy acts as a mediator between a student's English selfefficacy and his or her academic self-efficacy, and in fact, that non-native English language speaking international students' English self-efficacy predicts their self-efficacy in using English language to learn, and then predicts their academic self-efficacy. The results support Andrade (2009) and Lin and Scherz's (2014) studies that even though non-native English speaking international students came into the universities with certain levels of confidence in their English language proficiency, they still considered English language proficiency one of their academic challenges. Most importantly, these findings suggest the impact of using English for academic purposes cannot be undervalued in a university setting. There is a distinct difference between using English in social and communicative settings and using English to learn and perform academically. The confidence in using English to learn is one of the key components for international students to be successful academically.

Universities not only recruit international students, but also provide support services, such as English language classes, writing centers, or tutoring, to assist international students socially and academically (Andrade, 2006). Sometimes, international students do not want to spend their time taking extra English courses since their ultimate goals are completing their degrees (Andrade, 2009). Therefore, instructors can make it clear for international students that it is critical for them to learn how to use English academically, such as asking questions in the classroom, participating in class discussion, writing assignments or academic reports, or presenting in professional settings. In addition, universities can provide workshops or courses for non-native English speaking international students to learn how to use English in academic settings. Those efforts could facilitate international students' learning experiences in the United States and their success in their professional areas. 
Table 4. Regression weight estimates (Also in Figure 2-3

\begin{tabular}{|c|c|c|c|c|c|c|c|c|c|c|}
\hline \multirow[b]{2}{*}{ Dependent } & \multirow{2}{*}{\multicolumn{2}{|c|}{ Independent }} & \multicolumn{4}{|c|}{ Hypothesized Model } & \multicolumn{4}{|c|}{ Final Model } \\
\hline & & & $\begin{array}{l}\text { Std. } \\
\text { est. }\end{array}$ & $\begin{array}{l}\text { Unstd. } \\
\text { Est. }\end{array}$ & S.E. & $p$ & $\begin{array}{l}\text { Std. } \\
\text { est. }\end{array}$ & $\begin{array}{l}\text { Unstd } \\
\text {. Est. }\end{array}$ & S.E. & $p$ \\
\hline Listening & $\leftarrow$ & $\begin{array}{l}\text { English Self- } \\
\text { Efficacy }\end{array}$ & 0.90 & 1.11 & 0.05 & $* * *$ & 0.91 & 1.12 & 0.47 & $* * *$ \\
\hline Speaking & $\leftarrow$ & $\begin{array}{l}\text { English Self- } \\
\text { Efficacy }\end{array}$ & 0.94 & 1.00 & 0.04 & $* * *$ & 0.95 & 1.01 & 0.37 & \\
\hline Reading & $\leftarrow$ & $\begin{array}{l}\text { English Self- } \\
\text { Efficacy }\end{array}$ & 0.93 & 0.95 & 0.04 & $* * *$ & 0.93 & 0.95 & 0.04 & $* * *$ \\
\hline Writing & $\leftarrow$ & $\begin{array}{l}\text { English Self- } \\
\text { Efficacy }\end{array}$ & 0.93 & 1.00 & --- & -- & 0.93 & 1.00 & -- & -- \\
\hline $\begin{array}{l}\text { Using- } \\
\text { English-to- } \\
\text { Learn Self- } \\
\text { Efficacy }\end{array}$ & $\leftarrow$ & $\begin{array}{l}\text { English Self- } \\
\text { Efficacy }\end{array}$ & 0.97 & 1.00 & 0.03 & $* * *$ & 0.97 & 0.99 & 0.03 & $* * *$ \\
\hline $\begin{array}{l}\text { Academic } \\
\text { Self- } \\
\text { Efficacy }\end{array}$ & $\leftarrow$ & $\begin{array}{l}\text { Using-English- } \\
\text { to-Learn Self- } \\
\text { Efficacy }\end{array}$ & 0.68 & 0.74 & 0.33 & .03 & 0.57 & 0.62 & 0.06 & $* * *$ \\
\hline $\begin{array}{l}\text { Academic } \\
\text { Self- } \\
\text { Efficacy } \\
\end{array}$ & $\leftarrow$ & $\begin{array}{l}\text { English Self- } \\
\text { Efficacy }\end{array}$ & -0.12 & -0.14 & 0.34 & .69 & -- & --- & -- & -- \\
\hline
\end{tabular}

There were several limitations in the current study. First of all, this study employed a non-experimental quantitative research design with selfreport survey measures. Therefore, interpreting and generalizing the results into other populations and settings are limited. The survey completion rate was fine in the current study, but the majority of participants were graduate students. It might be interesting to see the difference in the relationship among English self-efficacy, self-efficacy in using English to learn, and academic self-efficacy between undergraduate and graduate students. In addition, the current study did not collect international students' majors, TOEFL scores, and GPAs. It might be meaningful to include this information into the model and compare the differences in the relationship among different majors.

Despite these concerns, the findings from the current study provided a model for understanding the relationship among English self-efficacy, self-efficacy in using English to learn, and academic self-efficacy. Selfefficacy in using English to learn was found to be a mediator. In addition, the results suggest English self-efficacy and self-efficacy in using English to learn are distinct constructs. Results suggest action from universities is warranted. First, instructors of core curriculum courses should be aware of the language demands inherent in their discipline. Secondly, universities should provide English course support with a more academic oriented 
curriculum that capitalizes on oral language development in an academic setting. These efforts will increase the chance of academic success for nonnative English speaking international students.

\section{REFERENCES}

Andrade, M. S. (2006). International students in English-speaking universities: Adjustment factors. Journal of Research in International Education, 5(2), 131-154. doi: 10.1177/1475240906065589

Andrade, M. S. (2009). The effects of English language proficiency on adjustment to university life. International Multilingual Research Journal, 3, 16-34. doi: $10.1080 / 19313150802668249$

Bandura, A. (1986). Social foundations of thought and action: A social cognitive theory. Englewood Cliffs, NJ: Prentice Hall.

Bandura, A. (1997). Self-efficacy: The exercise of control. New York, NY: Freeman.

Berman, R., \& Cheng, L. (2001). English academic language skills: Perceived difficulties by undergraduate and graduate students, and their academic achievement. Canadian Journal of Applied Linguistics, 4, 25-40.

Bong, M. (2001). Role of self-efficacy and task-value in predicting college students' course performance and future enrollment intentions. Contemporary Educational Psychology, 26, 553-570. doi: 10.1006/ceps.2000.1048

Brady-Amoon, P., \& Fuertes, J. N. (2011). Self-efficacy, self-rated abilities, adjustment, and academic performance. Journal of Counseling \& Development, 89(4), 431-438. doi: 10.1002/j.1556-6676.2011.tb02840.x

Burdett, J., \& Crossman, J. (2012). Engaging international students. Quality Assurance in Education, 20, 207-222. doi: 10.1108/09684881211240286

Choi, N. (2005). Self-efficacy and self-concept as predictors of college students' academic performance. Psychology in the Schools, 42(2), 197-205. doi: $10.1002 /$ pits. 20048

Eaton, M. J., \& Dembo, M. H. (1997). Differences in the motivation beliefs of Asian American and non-Asian students. Journal of Educational Psychology, 89, 443-440.

Fass-Holmes, B., \& Vaughn, A. A. (2015). Evidence that international undergraduates can succeed academically despite struggling with English. Journal of International Students, 5, 228-243.

Ferla, J., Valcke, M., \& Cai, Y. (2009). Academic self-efficacy and academic selfconcept: Reconsidering structural relationships. Learning and Individual Differences, 19(4), 499-505. doi: 10.1016/j.lindif.2009.05.004

Hair, J. F., Black, W. C., Babin, B. J., Anderson, R. E., \& Tatham, R. L. (2006). Multivariate data analysis (6th ed.). Upper Saddle River, NJ: Pearson.

Hox, J. J., \& Bechger, T. M. (1998). An introduction to structural equation modeling. Family Science Review, 11, 354-373. 
Kim, D.-H., Wang, C., Ahn, H. S., \& Bong, M. (2015). English language learners' self-efficacy profiles and relationship with self-regulated learning strategies. Learning and Individual Differences, 38, 136-142. doi: 10.1016/j.lindif.2015.01.016

Klassen, R. M. (2004). Optimism and realism: A review of self-efficacy from across-cultural perspective. International Journal of Psychology, 39, 205230.

Kline, R. B. (2010). Principles and practice of structural equation modeling (3rd ed.). New York, NY: Guilford Press.

Klomegah, R. Y. (2007). Predictors of academic performance of university students: An application of the goal efficacy model. College Student Journal, 41(2), 407.

Lin, S.-Y., \& Scherz, S. D. (2014). Challenges facing Asian international graduate students in the US: Pedagogical considerations in higher education. Journal of International Students, 4, 16-33.

Lin, Y., \& Wang, C. (2010). An empirical study of reading self-efficacy and the use of reading strategies in the Chinese EFL context. The Asian EFL Journal Quarterly, 12, 144-162.

Luo, J., \& Jamieson-Drake, D. (2013). Examining the educational benefits of interacting with international students. Journal of International Students, 3, 85-101.

Messner, P. E., \& Liu, N. (1995). The test of English as a foreign language: Examination of the "cut-off scores" in US universities. International Journal of Educational Management, 9(2), 39-42. doi: 10.1108/ 09513549510082378

Meyers, L. S., Gamst, G., \& Guarino, A. J. (2006). Applied multivariate research: Design and interpretation. Thousand Oaks, CA: Sage.

Perry, C. J. (2016). Comparing international and American students' challenges: A literature review. Journal of International Students, 6, 712-721.

Pintrich, P. R., Smith, D. A. F., Garcia, T., \& McKeachie, W, J. (1993). Reliability and predictive validity of the motivated strategies for learning questionnaire (MSLQ). Educational and Psychological Measurement, 53(3), 801-813. doi: 10.1177/0013164493053003024

Pintrich, P. R., \& Schunk, D. H. (1996). Motivation in education: Theory, research, and applications. Englewood Cliffs, NJ: Prentice Hall.

Poyrazli, S., Arbona, C., Bullington, R., \& Pisecco, S. (2002). Adjustment issues of Turkish college students studying in the United States. College Student Journal, 35(1), 52.

Poyrazli, S., Arbona, C., Nora, A., McPherson, R., \& Pisecco, S. (2002). Relatino between assertiveness, academic self-efficacy, and psychosocial adjustment among international graduate students. Journal of College Student Development, 43, 632-642.

Poyrazli, S., \& Lopez, M. D. (2007). An exploratory study of perceived discrimination and homesickness: A comparison of international students 
and American students. Journal of Psychology, 141, 263-280. doi: 10.3200/JRLP.141.3.263-280

Rahimi, A., \& Abedini, A. (2009). The interface between EFL learners' self-efficacy concerning listening comprehension and listening proficiency. NovitasRoyal, 3(1), 14-28.

Ramburuth, P. (2001). Language diversity and the first-year experience: Implications for academic achievement and language skills acquisition. Journal of the First-Year Experience \& Students in Transition, 13(2), 7593.

Ruiz, N. G. (2014, August). The geography of foreign students in U.S. higher education: Origins and destinations. Retrieved from http://www.brookings.edu/ /media/research/files/reports/2014/08/foreignstudents/foreign_students_final.pdf

Salili, F., Chui, C. Y., \& Lai, S. (2001). The influence of culture and context on students' motivational orientation and performance. In F. Salili, C. Y. Chiu, \& Y. Y. Hong (Eds.), Student motivation: The culture and context of learning (pp. 221-247). New York, NY: Kluwer.

Schunk, D. H., \& Pajares, F. (2002). The development of academic self-efficacy. In A. Wigfield, \& J. S. Eccle. (Eds.), Development of achievement motivation (pp. 15-31). San Diego, CA: Academic Press.

Sherry, M., Thomas, P., \& Chui, W. H. (2010). International students: A valuable student population. Higher Education, 60, 33-46. doi: 10.1007/s10734009-9284-Z

Solberg, V. C., O’Brien, K., Villareal, P., Kennel, R., \& Davis, B. (1993). Selfefficacy and Hispanic college students: Validation of the college selfefficacy instrument. Hispanic Journal of Behavioral Sciences, 15, 80-95. doi: 10.1177/07399863930151004

Solberg, V. C., O’Brien, K., Villareal, P., Kennel, R., \& Davis, B. (1998). Examination of self-efficacy, social support, and stress as predictors of psychological and physical distress among Hispanic college students. Hispanic Journal of Behavioral Sciences, 19, 182-201. doi: 10.1177/ 07399863970192006

Stoynoff, S. (1997). Factors associated with international students' academic achievement. Journal of Instructional Psychology, 24, 56-68.

Tabachnick, B. G., \& Fidell, L. S. (2007). Using multivariate statistics (5th ed.). Boston, MA: Pearson.

Ullman, J. B., \& Bentler, P. M. (2013). Structural equation modeling. In I. B. Winner (Ed.), Handbook of psychology (2nd ed., pp. 661-690). Hoboken, NJ: Wiley.

Wang, C. (2004). Self-regulated learning strategies and self-efficacy beliefs of children learning English as a second language (Doctoral dissertation). Retrieved from http://www.ohiolink.edu/etd/ 
Wang, C., Kim, D.-H., Bai, R., \& Hu, J. (2014). Psychometric properties of a selfefficacy scale for English language learners in China. System, 44, 24-33. doi: 10.1016/j.system.2014.01.015

Whang, P. A., \& Hancock, G. R. (1994). Motivation and mathematics achievement: Comparisons between Asian-American and Non-Asian students. Contemporary Educational Psychology, 19, 302-322. doi: 10.1006/ceps. 1994.1023

Yan, W., \& Gaier, E. L. (1994). Causal Attributions for College Success and Failure An Asian-American Comparison. Journal of Cross-Cultural Psychology, 25(1), 146-158. doi: 10.1177/0022022194251009

Zajacova, A., Lynch, S. M., \& Espenshade, T. J. (2005). Self-efficacy, stress, and academic success in college. Research in Higher Education, 46(6), 677706. doi: 10.1007/s11162-004-4139-z

Zong, J., \& Batalova, J. (2016, May). International students in the United States. Migration Policy Institute. Retrieved from http://www.migrationpolicy. org/article/international-students-united-states

CHIH-HSUAN WANG, PhD, is an assistant professor of education. Her research is focused on motivation and assessment in different learning settings, and the impact of using technology on teaching and learning process. Email: wangchi@auburn.edu

JAMIE HARRISON, EdD, is an assistant professor of ESOL education. She is interested in research related to teacher beliefs and practices, and the experiences of non-native English speakers in a variety of settings. Email: j1h0069@auburn.edu

VICTORIA CARDULLO, PhD, is an assistant professor of education. Her research is focused on metacognition and the impact of metacognitive strategies on digital literacies. Email: vmc0004@auburn.edu

XI LIN, PhD, is an adjunct faculty of education. Her research is focused on learners' motivation in e-learning and ways of enhancing teaching quality through using education technology. Email: xilin@auburn.edu

Manuscript submitted: September 1, 2016

Manuscript revised: December 16, 2016 Accepted for publication: February 10, 2017 